\title{
Effect of urea-molasses mineral block (UMMB) and medicated- UMMB supplementation on growth performance and feed gain ratio in goat kids
}

\author{
M.K. Gendley and S.P. Tiwari
}

\begin{abstract}
Forty eight nondescript breed of growing goat kids (6-9 months) were selected randomly on body weight basis and divided into three groups having four replicates (four animals in each replicate) to assessthe effect of urea-molasses mineral block (UMMB) and medicated-UMMB on their growth performance for 90 days. Group one $\left(T_{1}\right)$ was fed with roughage consisting of sola grasses (Aeschynomene indica $L$. ) and rhea leaves (Acacia leucophloea Roxb.) ad lib in equal proportion. The concentrate mixture (7\% DCP and $60 \%$ TDN) ranging from 150 to 250 g was fed to different kids depending on their body weight to meet protein and energy requirement. Group two $\left(T_{2}\right)$ was fed with the same roughage and concentrate mixture, in addition to ad lib supplementation of UMMB. Group three $\left(\mathrm{T}_{3}\right)$ was fed with the same roughage and concentrate mixture, in addition to medicated-UMMB (Fenbendazole @ $0.5 \mathrm{~g} / \mathrm{kg}$ feed block) ad lib for 10 days followed by un-medicated UMMB during rest of the trial period. The overall dry matter intake ( $499.38 \mathrm{~g} /$ day) and average body weight gain ( $54.23 \mathrm{~g} /$ day) of goat kids were the highest $(p<0.01)$ when fed with feed mixture containing medicated-UMMB. The UMMB and M-UMMB can be incorporated in the conventional feeding practice of goat kids for their better growth and development.
\end{abstract}

Keywords: UMMB, medicated-UMMB, goat kid

\section{Introduction}

Goats in the villages are reared traditionally on a forage-based diets and the practice of supplementation is not common. This traditional feeding system without supplementation is insufficient to satisfy the nutritional needs of the goats thus, resulting in poor growth performance of the kids. In multiple litters of local breeds, low live weights at 90 days of age with wide variations from 5 to $10 \mathrm{~kg}$ per animal and high kid mortality rate of $16 \%$ during the first three months have been observed when goat kids were fed only with forage-based diets (Saddulet al., 1999).

Molasses is the major by-product of sugar industry and it is a highly palatable product and a good source of energy for kids, too. Urea molasses mineral blocks (UMMB) provide a readily available source of energy in the form of molasses, nitrogen (both from protein and non-protein sources), fiber and

Department of Animal Nutrition, College of Veterinary Science and Animal Husbandry, Chhattisgarh Kamdhenu University, Durg, India

*Corresponding Author: drgmanoj.ann@gmail.com 
minerals. Successful utilization of UMMB in different parts of the world has been reported by Hadjipanayiotou (1996). Hence, this study evaluated the impact of UMMB supplementation to forage-based diet improve growth of goat kids under a rural setting.

\section{Materials and Methods}

Forty eight growing kids of 6-9 months old, belonging to nondescript breed were selected randomly on the body weight basis. The animals were divided into three groups having four replicates (four animals per replicate). Standard housing and management conditions were maintained throughout the experimental period of 90 days. Daily feed intake of kids was determined by subtracting leftover dry matter (DM) from the amount of dried feed offered. Recording of body weight of kids was done fortnightly and daily weight gain was calculated to determine the growth pattern and feed gain ratio of kids.

Roughage fed to the kids of all groups was prepared by dried sola grass (Aeschynomene indica L) and rhea leaves (Acacia leucophloea Roxb.) in equal proportion. The concentrate mixture given in addition to roughage to kids consisted of $25 \%$ of de-oiled rice bran (DORB), $42 \%$ of maize, $30 \%$ of de-oiled soybean cake, $2 \%$ of pre-mixes and $1 \%$ of common salt. The concentrate mixture was fed according to the recommendations of NRC (1981). The nutritive value of the diet was adjusted to contain $7 \%$ DCP and $60 \%$ TDN. Kids of the second group $\left(T_{2}\right)$ was fed with urea-molasses mineral block (UMMB) ad lib in addition to control diet whereas the kids of third group $\left(T_{3}\right)$ were fed with medicatedUMMB for the first 10 days followed by un-medicated UMMB for the rest of the period of the experiment in addition to $\mathrm{T}_{1}$ diet.

A technology was adopted for the preparation of UMMB by using locally available feed ingredients such as $44 \%$ of molasses, $10 \%$ of maize, $11 \%$ of de-oiled rice bran, $11 \%$ of de-oiled soy cake, $10 \%$ of urea, $5 \%$ of quick lime, $5 \%$ of bentonite, $3 \%$ of mineral mixture and $1 \%$ of common salt. Known quantity of molasses were taken in a container and heated at $60^{\circ} \mathrm{C}$ for the removal of excess moisture. Thereafter, the ingredients were mixed with molasses in order of urea, mineral mixture, common salt, quick lime, soybean cake (de-oiled), bentonite, rice bran (de-oiled) and maize. The mixture was set in a wooden mold (9"x 6"). After removal of the molds, the blocks were arranged in the drying area under shade with proper ventilation for 24 to 72 hours. The medicated-UMMB (M-UMMB) was prepared with the addition of $0.5 \mathrm{~g}$ Fenbendazole/kg UMMB.

Feed samples were analyzed for proximate principles as described in AOAC (1995) and data were subjected to one way ANOVA as per Snedecor and Cochran (1989). 


\section{Results and Discussion}

Dry matter (DM) intake of goat kids fed with $\mathrm{T}_{3}$ was significantly higher $(\mathrm{p}<0.01)$ than those in group $\mathrm{T}_{1}$ and $\mathrm{T} 2$. The DM intake of group $\mathrm{T} 1$ and $\mathrm{T} 2$ were similar throughout the experimental period (Table 1). Findings of the present study differed from Tiwari et al (2011) who reported that there were no significant differences when the kids were supplemented with UMMB at $4 \%$ of the body weight. The difference in findings could be due to feeding of low amount of UMMB, which could not have promoted the growth of ruminal micro flora in goat kids up to the optimal level. The DM intake was found to be higher with the supplementation of UMMB and M-UMMB, while the kids in the later recorded the highest DM intake. This may be due to effect of M-UMMB in pest and disease control of the animals as explained Avilla (1995).

Table 1. The effect of dietary supplementation of UMMB and M-UMMB on performance of the goat kids in various study groups

\begin{tabular}{lccccc}
\hline Parameters & $\begin{array}{c}\mathrm{T}_{1} \\
(\mathrm{PC})\end{array}$ & $\begin{array}{c}\mathrm{T}_{2} \\
(\mathrm{PC}+\mathrm{UMMB})\end{array}$ & $\begin{array}{c}\mathrm{T}_{3} \\
(\mathrm{PC}+\mathrm{M}-\mathrm{UMMB})\end{array}$ & $\mathrm{SEM}$ & Sig. \\
\hline $\begin{array}{l}\text { DM intake } \\
\quad(\mathrm{g} / \text { day })\end{array}$ & $415.68^{\mathrm{b}}$ & $402.86^{\mathrm{b}}$ & $499.38^{\mathrm{a}}$ & 16.41 & $* *$ \\
$\begin{array}{l}\mathrm{DM} \text { intake } \\
\left(\mathrm{g} / \mathrm{kg} \mathrm{W}^{0.75} / \mathrm{d}\right)\end{array}$ & $74.15^{\mathrm{b}}$ & $70.62^{\mathrm{b}}$ & $86.73^{\mathrm{a}}$ & 3 & $* *$ \\
$\begin{array}{l}\text { Average body gain } \\
\text { (g/day) }\end{array}$ & $44.67^{\mathrm{c}}$ & $50.64^{\mathrm{b}}$ & $54.23^{\mathrm{a}}$ & 1.78 & $* *$ \\
Feed: gain ratio & $9.57^{\mathrm{a}}$ & $8.28^{\mathrm{b}}$ & $9.52^{\mathrm{a}}$ & 0.35 & $* *$ \\
\hline
\end{tabular}

$\mathrm{T}_{1}, \mathrm{~T}_{2}$ and $\mathrm{T}_{3}$ : groups of goat kids fed with different feed mixtures; PC: Positive control, UMMB: urea-molasses mineral block, M-UMMB: medicated urea-molasses mineral block. SEM: standard error of mean, Sig.: Significance; Within a row, means followed by the same letter are not significantly different; ${ }^{*} p<0.05,{ }^{* *} p<0.01$

There were significant effect $(p<0.01)$ of dietary supplementation of UMMB (group $\mathrm{T}_{2}$ ) and M-UMMB (group III) on average body gain. Overall weight gain was highest in group III, followed by the group II. The least weight gain was observed in PC (group I). Significantly highest overall feed gain ratio was recorded in UMMB supplemented group (8.28) followed by M-UMMB (9.52) and the lowest in Positive Control group I (9.57).

\section{Conclusion}

The result indicated that conventional concentrate feeding can be supplemented with UMMB for the better growth performance of goat kids. The $U M M B$ and $M-U M M B$ increased feed intake, live weight gain, feed gain ratio and net return and thus can be economically incorporated in the conventional feeding practice of goats. 


\section{References}

AOAC (1995): Official Methods of Analysis. $16^{\text {th }}$ Edition. Association of Official Analytical Chemists, Washington, D.C.

Avilla, H.F. (1995): Production and utilisation of urea-molasses mineral block in the Philippines Bureau of Animal Industry, Research Division, Quezon City, Philippines.

Hadjipanayiotou, M. (1996): Performance of Friesian heifers on urea-blocks and of Chios ewes on blocks and other supplements. Livestock Res for Rural Develop. 8(1): $125-698$

NRC (1981): Nutrient requirements of domestic animals. National Research Council, Washington, D.C.

Saddul, D., Seenevassen Pillay, M.M., Ramnauth, R.K, Fakim, R., Lam S.Y.R., Saraye, G., Toolsee, P. and Boodoo, A.A. (1999): Evaluation of the smallholder goat production system in Mauritius. Proc. Annual Meeting of Agricultural Scientists, $12^{\text {th }}$ September, pp-221-230.

Snedecor, G.W. and Cochran, W.G. (1989): Statistical Methods, Eighth Edition, Iowa State University Press.

Tiwari, M.R.E., Shrestha, B.K., Panday, L.N. and Mandal, P. (2011): Comparison of growth performance of Khari goats fed with different level of rice bran and ureatreated rice straw (UTRS) in fodder-based diets. Nepal J. Science and Technol. 12(1): 55-60. 